\title{
REPORTS AND AWARENESS OF RESTAURANT TAXPAYERS AND SOCIALIZATION OF THE SYSTEM TO INCREASE PAD IN BANJARBARU CITY
}

\author{
Edy Joko Soewanto \\ Sekolah Tinggi Ilmu Ekonom Pancasetia Banjarmasin \\ Jl. Ahmad Yani Km. 5.5 Banjarmasin \\ faeyzahabibi616@gmail.com
}

\begin{abstract}
Reports and Awareness of Restaurant Taxpayers and Socialization of the System to Increase PAD in Banjarbaru City, under the guidance of Mr. H. Nurus Sjamsi and Mr. H. Ihil S Baron, as supervisors I and II.

This research was conducted with the aim of analyzing the simultaneous effect of reporting, taxpayer awareness and system socialization on the PAD of Banjarbaru City; analyze the partial effect of reporting, awareness of taxpayers and the socialization of the system to PAD Kota Banjarbaru; and analyze the reporting variables, awareness of taxpayers and socialization that have a dominant effect on PAD of Banjarbaru City.

Analysis of the data used in this study is quantitative descriptive with a sample of 80 taxpayer respondents, using multiple linear regression test data analysis.

The results of the study concluded that the reporting, awareness of taxpayers and simultaneous socialization of the system significantly influence the original income of the Banjarbaru City. Partially reporting, awareness of taxpayers and socialization have a significant effect on the original income of the Banjarbaru City. The variable that has dominant influence on the original income of the Banjarbaru City is socialization, because the significant value is greater than the other variables.
\end{abstract}

Keywords: Reporting, Taxpayer Awareness, System Socialization, PAD Banjarbaru City

\begin{abstract}
Abstrak: Laporan Dan Kesadaran Wajib Pajak Restoran Serta Sosialisasi Sistem Untuk Meningkatkan PAD Kota Banjarbaru, dibawah bimbingan Bapak H. Nurus Sjamsi dan Bapak H. Ihil S Baron, selaku dosen pembimbing I dan II.

Penelitian ini dilaksanakan dengan tujuan untuk menganalisis pengaruh simultan dari pelaporan, kesadaran wajib pajak dan sosialisasi sistem terhadap PAD Kota Banjarbaru; menganilisis pengaruh parsial dari pelaporan, kesadaran wajib pajak dan sosialisasi sistem terhadap PAD Kota Banjarbaru; dan menganalisis dari variabel pelaporan, kesadaran wajib pajak dan sosialisasi yang berpengaruh dominan terhadap PAD Kota Banjarbaru.

Analisis data yang digunakan dalam penelitian ini adalah deskriptif kuantitatif dengan sampel sebanyak 80 responden wajib pajak, menggunakan analisis data uji regresi linier berganda.

Hasil penelitian menyimpulkan bahwa pelaporan, kesadaran wajib pajak dan sosialisasi sistem secara simultan berpengaruh signifikan terhadap pendapatan asli daerah Kota Banjarbaru. Secara parsial pelaporan, kesadaran wajib pajak dan sosialisasi berpengaruh signifikan terhadap pendapatan asli daerah Kota Banjarbaru. Variabel yang berpengaruh dominan terhadap pendapatan asli daerah Kota Banjarbaru adalah sosialisasi, karena nilai signifikan lebih besar pengaruhnya dibanding dengan variabel yang lain.
\end{abstract}

Kata kunci: Pelaporan, Kesadaran Wajib Pajak, Sosialisasi Sistem, PAD Kota Banjarbaru 


\section{PENDAHULUAN}

Negara Kesatuan Republik Indonesia terdiri dari beberapa Provinsi dan Kabupaten/Kota, sehingga untuk dapat meningkatkan pembangunan atau pemerataan pembangunan suatu daerah, pemerintah kabupaten/kota tidak bisa mengandalkan sepenuhnya kepada pemerintah provinsi maupun pemerintah pusat. Karena itulah daerah kabupaten/kota diberikan kewenangan untuk mengurus dan mengatur rumah tangganya sendiri, yang kita kenal sebagai otonomi daerah. Sejak diberlakukannya undang-undang Nomor 32 tahun 2004 tentang otonomi daerah, Pajak menjadi salah satu sumber penerimaan Daerah yang memegang peranan penting sebagai penggerak atau dana untuk pembangunan.

Dalam rangka memaksimalkan pendapatan asli daerah ini, pemerintah daerah berupaya keras untuk mencari sumber-sumber pendapatan yang potensial seraya mengoptimalkan sumbersumber pendapatan asli daerah yang telah dipungut selama ini.

Setiap daerah walaupun diberikan jenis sumber pendapatan yang sama, tetapi tidak berarti setiap daerah memiliki jumlah pendapatan yang sama dalam membiayai kewenangannya. Pedapatan daerah tergantung pada kondisi yang dimiliki setiap daerah, misalnya jumlah penduduk, kekayaan daerah, luas wilayah dan tingkat pertumbuhan ekonomi.

Perimbangan Keuangan antara Pemerintah Pusat dan Pemerintah Daerah menyebutkan bahwa sumber-sumber pendapatan daerah adalah pendapatan Berdasarkan UndangUndang Nomor 33 Tahun 2004 tentang Asli Daerah (PAD), dana perimbangan, dan pendapatan daerah yang sah.

Pendapatan Asli Daerah menurut UndangUndang Nomor 33 Tahun 2004 yaitu : Phjak Daerah, Retribusi Daerah, Hasil pengelolaan kekayaan daerah yang dipisahkan; dan Lain-lain PAD yang sah. Retribusi menurut UndangUndang nomor 28 tahun 2009 adalah pungutan daerah sebagai pembayaran atas jasa atau pemberian izin tertentu yang khusus disediakan dan/atau diberikan oleh Pemerintaan Daerah untuk kepentingan pribadi atau badan. Peraturan Walikota Kota Banjarbaru Nomor 65 Tahun 2017 perubahan atas Peraturan Walikota Banjarbaru Nomor 77 Tahun 2016 tentang
Petunjuk Pelaksanaan Pemungutan Pajak Restoran.

Untuk mengembangkan dan memotivasi sumber keuangan Daerah, pemerintahan Daerah diberi peluang menggali sumber-sumber pendapatan yang cukup potensial seperti pajak dan retribusi untuk memberikan kontribusi yang signifikan terhadap Pendapatan Daerah. Oleh karena itu Pajak Daerah seperti Pajak Kabupaten atau Kota sangat berperan penting untuk membantu lancarnya jalan roda pemerintahan dan pembangunan daerah dalam rangka meningkatkan kesejahteraan masyarakat, hal ini dapat dimaklumi karena sumber penerimaan terbesar APBN atau APBD saat ini berasal dari pajak. untuk mendukung perannya yang begitu besar, masyarakat di Daerah diharapkan lebih peduli dan pengetahuan masyarakat harus ditingkatkan sehingga bisa memberikan kontribusi yang nyata untuk pembangunan Daerah. Jadi dengan demikian, pajak merupakan pungutan daerah yang penerimaannya harus ditingkatkan untuk mewujudkan pembangunan daerah seperti yang dikehendaki masyarakat daerah, karena seluruh rangkaian kegiatan pemerintah dan pembangunan memerlukan dana atau biaya yang sangat besar, dan ini tidak akan terwujud jika pemerintah daerah tidak bisa memaksimalkan potensi-potensi yang ada di daerahnya. Begitu juga daerah Kota Banjarbaru yang merupakan daerah otonomi seperti daerah otonomi lainnya yang ada di Indonesia bahwa untuk membiayai pengeluaran daerah, baik yang berupa pembiayaan rutin maupun pembangunan pastilah memerlukan dana yang begitu besar karena itu dinas pendapatan daerah selaku unsur pelaksana daerah diharuskan mampu menggali potensi-potensi pendapatan daerah dan usaha daerah lainnya secara optimal.

Keseluruhan penerimaan pajak daerah seperti yang diatas, memiliki peranan yang sangat penting bagi pendapatan daerah Kota Banjarbaru, penerimaan atau pemungutan tersebut merupakan pendapatan asli daerah yang dikumpulkan seluruh kecamatan yang yang ada di Kota Banjarbaru. Sehingga diharapkan setiap kecamatan dan instansi mampu memberikan kontribusi yang nyata untuk peningkatan penerimaan daerah, salah satunya pajak restoran. 
Pajak Restoran termasuk Pajak Kabupaten atau Kota, yang tarif jenis pajaknya sebesar $10 \%$ (sepuluh persen) yang ditetapkan sesuai dengan peraturan Daerah, karena dari berbagai pajak yang ada di Daerah Kota Banjarbaru, pajak restoran merupakan salah satu sumber penerimaan Daerah yang selalu meningkat, ini didasarkan karena jumlah pendapatan asli Daerah yang berasal dari pajak restoran sangat baik. Oleh karena itu Pemerintah Kota Banjarbaru berupaya menigkatkan pengelolaan pajak daerah dan mengoptimalkan penerimaan dengan memberikan sanksi administratif dan denda bagi wajib pajak yang menunggak pembayaran pajak dari berbagai sektor pajak, termasuk pajak restoran agar setiap tahun mengalami peningkatan.

Realisasi Pajak Restoran per Kecamatan dari tahun ketahun terus meningkat. Peningkatan pajak restoran tidak terlepas dari kesadaran Wajib pajak dalam melakukan pembayaran pajak restoran, pada lima kecamatan yang ada di Kota Banjarbaru menunjukkan peningkatan pajak restoran. Pada Kecamatan Banjarbaru Utara dengan nilai pajak restoran sebesar Rp. 3.479.000.735,02 di tahun 2015 meningkat cukup signifikan dari tahun ke tahun hingga tahun 2018 dengan nilai pajak sebesar Rp. 8.178.164.891,76 dengan nilai peningkatan pajak tertinggi jika dibandingkan dengan empat kecamatan yang lain. Kecamatan Banjarbaru Selatan dengan nilai pajak ditahun 2015 sebesar Rp. 2.500.531.778,30 mengalami peningkatan dalam 4 tahun terakhir hingga Rp. 5.878.056.015,95 di tahun 2018. Peningkatan pajak restoran ini juga terjadi di wilayah kecamatan Cempaka dimana pada tahun 2015 sebesar Rp. 1.114.367.422,94 meningkat dalam kurun waktu emapt tahun terakhir menjadi Rp. 2.619.568.441,89 di tahun 2018. Sementara untuk kecamatan Landasan Ulin dengan nilai pajak di tahun 2015 adalah sebesar Rp. 2.120.016.072,90 meningkat dalam empat tahun terakhir menjadi 4.983.569.230,91 di tahun 2018. Terakhir kecamatan Liang Anggang dengan nilai pajak sebesar Rp. 1.440.523.741,84 di tahun 2015 meningkat cukup signifikan hingga sebesar Rp. 3.386.271.400,49 di tahun 2018. Dari lima kecamatan, Kecamatan Banjarbaru Utara paling tinggi peningkatan nilai pajak restorannya, hal ini mengingat paling tinggi wajib pajaknya.
Dengan meningkatnya jumlah penduduk di Kota Banjarbaru banyak masyarakat dan investor baik dari dalam dan dari luar Kota Banjarbaru membuka investasi usaha warung makan, rumah makan dan restoran hal ini merupakan potensi yang dapat digali oleh pemerintah Kota Banjarbaru untuk menarik pajak restoran dan meningkatkan pendapatan asli daerah. Peningkatan nilai pendapatan dari sektor pajak restoran memang tidak proporsional seiring dengan meningkatnya wajib pajak restoran, hal ini dikarenakan kurangnya kesadaran wajib pajak restoran dalam melaporkan pendapatan restoran baik yang baru maupun yang sudah lama.

Peningkatan wajib pajak di Kota Banjarbaru tidak selalu diimbangi dengan peningkatan pendapatan daerah dari pajak restoran ini dikarenakan masih terdapat wajib pajak yang belum jujur dalam melaporkan dan membayar pajak. Ringannya sanksi yang diberikan oleh Badan Pengelolaan Pajak dan Retribusi Daerah (BPPRD) membuat wajib pajak yang tidak patuh dalam membayar pajak. Badan Pengelolaan Pajak dan Retribusi Daerah (BPPRD) harus membuat aturan yang tegas dalam upaya meningkatkan kesadaran wajib pajak agar taat dalam membayar pajak dan melakukan sosialisasi kepada calon wajib pajak dan wajib pajak.

Peningkatan pendapatan dari pajak restoran tidak terlepas dengan peran Pemerintah Kota Banjarbaru dalam melakukan sosialisasi pajak restoran dan memudahkan wajib pajak dalam membuat perijinan untuk usaha restoran serta meningkatnya kesadaran wajib pajak untuk membuat atau laporan SPTPD (surat pemberitahuan pajak daerah). Sedangkan penurunan pendapatan dari pajak restoran terjadi dikarenakan beberapa hal seperti : menurunnya tingkat kesadaran wajib pajak dalam melaporkan dan membayar pajak restoran, meningkatnya persaingan antara restoran mengakibatkan kalah bersaing sehingga terjadinya penutupan atau berhentinya aktifitas restoran, tempat yang kurang strategis serta menu makanan yang kurang bervariasi mengakibatkan ditinggal pelanggan.

Selain itu Pajak Restoran memberikan peranan yang cukup berarti bagi sektor PAD maupun sektor Pajak Daerah Kota Banjarbaru. Hal ini tergambar dalam kontribusi Pajak 
Restoran terhadap PAD Kota Banjarbaru sebagai berikut :

\section{Kontribusi Pajak Restoran Terhadap Pendapatan Asli Daerah \\ Kota Banjarbaru Tahun 2015-2018 (Dalam Rupiah)}

\begin{tabular}{|c|r|r|c|}
\hline Tahun & $\begin{array}{c}\text { Pajak restoran } \\
\text { (Rp.) }\end{array}$ & $\begin{array}{c}\text { PAD } \\
\text { (Rp.) }\end{array}$ & $\begin{array}{c}\text { Kontribu } \\
\text { si } \\
(\%)\end{array}$ \\
\hline 201 & 10.654 .439 .751$. & $68.929 .861 .464,9$ & 15 \\
5 & 00 & 1 & \\
\hline 201 & 12.534 .734 .964$. & 169.183 .937 .917$, & 7 \\
6 & 00 & 67 & \\
\hline 201 & 19.332 .619 .719$. & 107.011 .193 .120$, & 18 \\
7 & 00 & 00 & \\
\hline 201 & 25.045 .629 .981$. & 131.515 .643 .094$, & 19 \\
8 & 00 & 00 & \\
\hline
\end{tabular}

Berdasarkan data diatas terlihat bahwa kontribusi Pajak Restoran terhadap Pendapatan Asli Daerah (PAD) Kota Banjarbaru selama kurun waktu tiga tahun terakhir dengan ratarata15\%. Dapat terlihat dari tabel diatas, kontribusi dari sektor Pajak Restoran dari tahun ketahun selalu mengalami perubahan dalam artian kata selalu meningkat. Pajak Restoran dalam penerimaan daerah ini memberikan kontribusi yang baik pada setiap tahunnya.

Dimana tahun 2015 pajak restoran berkontribusi membangun PAD sebesar Rp. 10.654.439.751.00 atau sebesar 15\%. Tahun 2016 pajak restoran berkontribusi membangun PAD sebesar Rp. 12.534.734.964.00 atau sebesar 7\%. Pada tahun 2017 Pajak Restoran berkontribusi mambangun jumlah PAD sebesar Rp. 19.332.619.719.00 atau sebesar 18\%. Tahun 2018 Pajak Restoran berkontribusi membangun jumlah PAD mengalami peningkatan sebesar Rp. 25.045.629.981.00 atau 19\% dari jumlah Pendapatan Asli Daerah.

Keberhasilan pemungutan seperti yang telah digambarkan oleh tabel-tabel seperti yang diatas ditentukan oleh dua hal yaitu : kesadaran masyarakat untuk membayar pajak serta sikap dan kemampuan aparat pajak dalam melaksanakan tugasnya. Untuk itu pemerintah daerah dalam hal ini Badan Pengelolaan Pajak dan Retribusi Daerah Kota Banjarbaru mengambil strategi untuk meningkatkan Pendapatan Daerah dari sektor pajak restoran dengan cara sebagai berikut :

1. Dengan cara melakukan pengawasan terhadap restoran yang ada di Kota
Banjarbaru patuh atau tidak sebagai wajib pajak.

2. Menyempurnakan sarana dan prasarana yang dimiliki sehingga kinerja aparatur pajak semakin baik.

3. Melakukan penyuluhan atau pendataan langsung kelapangan terhadap restoranrestoran yang ada di Kota Banjarbaru.

4. Melaksanakan sosialisasi terhadap masyarakat dengan tujuan agar masyarakat mengerti arti pentingnya pajak dan retribusi bagi pembangunan daerah.

5. Memberikan selebaran atau pemberitahuan kepada masyarakat dan pengunjung yang sering makan/minum kerestoran bahwasannya restoran tersebut sudah dikenakan pajak dengan tarif $10 \%$.

6. Meningkatkan disiplin kerja pegawai yang tinggi.

Dari keterangan di atas dan kondisi yang telah penulis paparkan menunjukan bahwa Pendapatan Daerah dari sektor pajak restoran sangat berkontribusi nyata untuk peningkatan pembangunan di segala bidang, sehingga berdasarkan uraian di atas penulis mengangkat judul "Laporan Dan Kesadaran Wajib Pajak Restoran Serta Sosialisasi Sistem untuk meningkatkan PAD Kota Banjarbaru"

\section{LANDASAN TEORI \\ Laporan}

Laporan menjadi hal wajib bagi seseorang atau organisasi setelah melakukan sebuah kegiatan, penelitian, pengamatan, dan aktivitas lainnya. Laporan dibuat setelah semua aktivitas tersebut selesai dilakukan. Laporan yang baik harus memberikan ulasan-ulasan yang sesuai dengan kejadian nyata, jujur dan tidak mengadangada. Pengertian laporan menurut para ahli tentunya beragam. Hal ini karena cakupan laporan sangatlah luas. Laporan bisa dibagi berdasarkan kegiatannya, waktu pembuatannya, aspek yang mendasari pembuatannya dan lain sebagainya.

Laporan bisa diartikan sebagai bentuk pertanggung jawaban atas suatu tindakan atau kegiatan yang telah dilakukan. Berikut ini adalah pengertian laporan menurut para ahli :

1. Menurut Alawiyah, laporan adalah informasi dari seorang petugas atau pejabat kepada petugas atau pejabat lain dalam suatu sistem administrasi. 
2. Menurut Mulyadi, laporan adalah keluaran sistem informasi akutansi yang berbentuk hasil cetak computer dan tayangan pada layar monitor komputer.

3. Menurut Keraf, laporan adalah salah satu komunikasi dimana penulis bisa menyampaikan informasi kepada orang lain atau organisasi karena tanggung jawab yang dibebankan kepadanya

4. Menurut Indah, laporan adalah karangan yang berisikan paparan peristiwa atau kegiatan yang telah dilakukan.

5. Menurut Rama dan Jones, laporan adalah presentasi data yang telah terformat dan teroganisasi dengan baik.

6. Menurut Soegito, laporan adalah informasi yang didukung oleh data-data yang lengkap dan sesuai dengan fakta yang terjadi. Data harus disusun sedemikian rupa sehingga dapat dipercaya dan mudah untuk dipahami. Wajib pajak diberikan kepercayaan oleh Peraturan Daerah untuk menghitung, memotong, menyetorkan dan melaporkan sendiri jumlah pajak dibayarkan kepada Badan Pengelolaan Pajak dan Retribusi Daerah. Sedangkan tata cara pelaporannya sebagaimana disebutkan di dalam pasal 11 ayat $(1,2,3,4,5)$ antara lain sebagai berikut :

1. Wajib pajak terlebih dahulu mengisi surat pemberitahuan pajak daerah (SPTPD) yang hars diisi dengan jelas, benar dan lengkap.

2. Setelah itu disampaikan kepada Walikota sesuai dengan jangka waktu yang ditetapkan oleh walikota.

3. Bentuk, isi dan tata cara pengisisn SPTPD ditetapkan lebih lanjut oleh walikota.

\section{Kesadaran Wajib Pajak}

Kesadaran wajib pajak adalah kondisi dimana Wajib Pajak mengetahui, mengakui menghargai dan menaati ketentuan perpajakan yang berlaku serta memiliki kesungguhan dan keinginan untuk memenuhi kewajiban pajaknya. Menurut Asri (2009) wajib pajak dikatakann memiliki kesadaran apabila :

1. Mengetahui adanya Undang-Undang dan ketentuan perpajakan.

2. Mengetahui fungsi pajak untuk pembiayaan negara.

3. Memahami bahwa kewajiban perpajakan harus dilaksanakan sesuai dengan ketentuan yang berlaku.
4. Memahami fungsi pajak untuk pembiayaan negara.

5. Menghitung, membayar, melaporkan pajak dengan sukarela.

6. Menghitung, membayar, melaporkan pajak dengan benar.

Kesadaran wajib pajak dalam membayar pajak merupakan prilaku wajib pajak berupa pandangan atau perasaan yang melibatkan pengetahuan, keyakinan dan penalaran disertai kecendrungan untuk bertindak sesuai stimulus yang diberikan oleh sistem dan ketentuan pajak tersebut (Fikriningrum, 2012).

Faktor penting dalam melaksanakan sistem perpajakan baru (self assessment system) adalah kesadaran dan kepatuhan yang tinggi dari wajib pajak (Priyantini, 2008). Masalah pengumpulan pajak dari masyarakat seringkali terkendala karena kesadaran pajak yang kurang (Lerche, 1980) dalam (Jatmiko, 2006).

\section{Sosialisasi}

Menurut Rohmawati, Prasetyono, Rimawati (2013), sosialisasi perpajakan adalah upaya yang dilakukan oleh pemerintah untuk memberikan sebuah pengetahuan kepada masyarakat dan khususnya wajib pajak agar mengetahui tentang segala hal mengenai perpajakan baik peraturan maupun tata cara perpajakan melalui metode-metode yang tepat. Sosialisasi tidak hanya dapat meningkatkan pengetahuan tentang pajak yang nantinya dapat berdampak pada peningkatan kesadaran wajib pajak itu sendiri. Namun, sosialisasi perpajakan diharapkan dapat meningkatkan kepatuhan wajib pajak sehingga jumlah penerimaan pajak dapat bertambah sesuai target.

Dalam upaya untuk meningkatkan pemahaman dan kesadaran wajib masyarakat tentang hak dan kewajiban perpanjakannya harus terus dilakukan karena beberapa alasan, antara lain :

a. Program ekstensifikasi yang terus menerus dilakukan Badan Pengelolaan Pajak dan Retribusi Daerah diperkirakan akan menambah jumlah Wajib Pajak Baru yang membutuhkan sosialisasi/penyuluhan.

b. Tingkat kepatuhan Wajib Pajak terdaftar masih memiliki ruang yang besar untuk ditingkatkan

c. Peraturan dan kebijakan pajak yang bersifat dinamis 
Setelah mengetahui makna sosialisasi dengan indikator menurut Arya Yogatama (2014) :

\section{a. Tatacara Sosialisasi}

Sosialisasi yang diadakan harus sesuai dengan peraturan pajak yang berlaku. Sosialisasi perpajakan dilakukan oleh pihak pemerintah yang ditujukan kepada wajib pajak agar mendapatkan pengetahuan dan pemahaman pajak yang memadai.

b. Frekuensi Sosialisasi

Sosialisasi pajak pajak harus dilakukan secara teratur karena peraturan dan tatacara pembayaranpajak biasanya mengalami perubahan. Sosialisasi pajak yang dilakukan secara teratur juga akan terus memberikan informasi yang terbaru sehingga wajib pajak dapat meminamilisir kesalahan saat menjalankan kewajiban pajaknya jika terjadi perubahan peraturan atau tatacara perpajakan.

c. Kejelasan Sosialisasi

Sosialisasi yang diadakan harus dapat menyampaikan semua informasi kedalam wajib pajak. Sosialisasi harus disampaikan dengan jelas agar wajib pajak dapat memahami informasi yang diberikan.

d. Pengetahuan Perpajakan

Sosialisasi yang diadakan bertujuan memberikan informasi pada wajib pajak. Sosialisasi akan sukses jika informasi yang diberikan dapat diterima oleh wajib pajak sehingga wajib pajak memiliki pengetahuan pajak yang memadai agar memudahkan wajib pajak dalam menjalankan kewajiban pajaknya.

\section{Pendapatan Asli Daerah}

Pendapatan asli daerah merupakan pendapatan yang berasal dari pemanfaatan dan penggalian potensi yang dimiliki oleh daerah. Di era otonomi daerah ini, daerah dituntut untuk mencari alternatif lain yang dimanfaatkan sebagai bentuk inivasi sistem guna meningkatkan pendapatan daerah. Menurut Muluk (2010 : 77).

Menurut Halim (2012 : 67) menyatakan bahwa saham adalah : semua penerimaan daerah yang berasal dari sumber ekonomi asli daerah. Adapun komponen dari PAD dibagi menjadi empat jenis yaitu :

a. Pajak Daerah b. Retribusi Daerah

c. Hasil pengelolaan daerah yang dipisahkan

d. Lain- lain pendapatan asli daerah yang sah. Berdasarkan uraian diatas secara umum pengertian Pendapatan Asli Daerah dapat disimpulkan adalah suatu komponen sumber penerimaan lainnya berupa dana perimbangan, pinjaman daerah dan lain-lain. Pendapatan daerah yang sah juga sisa anggaran tahun sebelumnya dapat ditambahkan sebagai sumber pendanaan penyelenggranaan pemerintah di daerah.

Jenis pajak kabupaten / kota terdiri atas :

1. Pajak hotel

Pajak hotel adalah pajak atas pelayanan yang disediakan oleh hotel. Hotel adalah fasilitas penyedia jasa penginapan dengan dipungut bayaran.

2. Pajak restoran

Pajak restoran adalah pajak atas pelayanan yang disediakan oleh restoran. Restoran adalah fasilitas penyedia makanan dan minuman dengan dipungut bayaran yang mencakup rumah makan dan sejenisnya.

3. Pajak hiburan

Pajak hiburan adalah pajak atas penyelenggaraan hiburan. Hiburan adalah semua jenis tontonan, permainan dan keramaian yang dinikmati dengan dipungut bayaran.

4. Pajak reklame

Pajak reklame adalah pajak atas penyelenggaraan reklame. Reklame adalah benda atau alat yang bentuk corak ragamnya dirancang untuk tujuan memperkenalkan, mempromosikan yang dapat dilihat / dibaca oleh umum.

5. Pajak penerangan jalan

Pajak penerangan jalan adalah pajak atas penggunaan tenaga listrik yang dihasilkan sendiri ataupun sumber lain.

6. Pajak mineral bukan logam dan batuan Pajak mineral bukan logam dan batuan adalah pajak atas pengambilan mineral bukan logam dan batuan, baik dari sumber alam di dalam dan/atau permukaan bumi untuk dimanfaatkan

7. Pajak air tanah adalah pajak atas pengambilan dan atau pemanfaatan air tanah.

8. Pajak parkir 
Pajak parkir adalah pajak atas penyelenggaraan tempat parkir diluar badan jalan, baik yang disediakan berkaitan dengan pokok usaha maupun yang disediakan sebagai suatu usaha, termasuk penyediaan tempat penitipan kendaraan.

9. Pajak sarang burung wallet

Adalah pajak atas pengambilan dan pengusahaan sarang burung wallet.

10. Pajak bea perolehan atas tanah dan bangunan (BPHTB) adalah pajak perolehan atas hak tanah dan bangunan.

11. Pajak Bumi dan Bangunan perdesaan dan perkotaan (PBB P2) adalah pajak atas bumi dan bangunan yang dimiliki atau dikuasai serta dimanfaatkan oleh orang pribadi atau badan, kecuali kawasan yang digunakan untuk kegiatan usaha perkebunan, kehutanan dan pertambangan.

Tarif pajak daerah yang dipungut oleh pemerintah daerah telah diatur dalam UndangUndang nomor 28 tahun 2009 yang ditetapkan dengan pembatasan tarif paling tinggi berbeda untuk setiap jenis pajak.

Berikut tarif pajak daerah menurut UndangUndang Nomor 28 tahun 2009:

Tarif Pajak Daerah Menurut UndangUndang Nomor 28 Tahun 2009

\begin{tabular}{|c|l|r|}
\hline No. & \multicolumn{1}{|c|}{ Pajak Pajak Provinsi } & $\begin{array}{r}\text { Tarif } \\
\text { Pajak }\end{array}$ \\
\hline \multicolumn{3}{|c|}{} \\
\hline 1 & Pajak Kendaraan Bermotor & $5 \%$ \\
\hline 2 & $\begin{array}{l}\text { Bea Balik Nama Kendaraan } \\
\text { Bermotor }\end{array}$ & $10 \%$ \\
\hline 3 & $\begin{array}{l}\text { Pajak Bahan Bakar Kendaraan } \\
\text { Bermotor }\end{array}$ & $5 \%$ \\
\hline 4 & Pajak Air Permukaan & $20 \%$ \\
\hline 5 & Pajak Rokok & $10 \%$ \\
\hline \multicolumn{2}{|c|}{ Pajak Daerah Kabupaten / Kota } \\
\hline 1 & Pajak hotel & $10 \%$ \\
\hline 2 & Pajak restoran & $10 \%$ \\
\hline 3 & Pajak hiburan & $25 \%$ \\
\hline 4 & Pajak reklame & $25 \%$ \\
\hline 5 & $\begin{array}{l}\text { Pajak mineral bukan logam dan } \\
\text { batuan }\end{array}$ & $30 \%$ \\
\hline 6 & Pajak parkir & $20 \%$ \\
\hline 7 & Pajak air tanah & $30 \%$ \\
\hline 8 & Pajak sarang burung walet & $5 \%$ \\
\hline 9 & Pajak bumi dan bangunan \\
\hline 10 & $\begin{array}{l}\text { Pajak bea perolehan Hak atas } \\
\text { bangunan }\end{array}$ & \\
\hline
\end{tabular}

\section{Pajak Restoran}

Menurut Siahaan P Mariot (2005 : 271) pajak restoran adalah pajak atas pelayanan restoran. Menurut Yani Ahmad (2002 : 48) pajak restoran adalah Pajak atas pelayanan Restoran. Restoran adalah tempat menyantap makanan dan minuman yang disediakan dengan dipungut bayaran, tidak termasuk usaha jasa boga dan catering.

Pemungutan pajak restoran di Indonesia saat ini didasarkan Undang-Undang Nomor 28 tahun 2009 yang merpakan perubahan atas Undang-Undang nomor 18 tahun 1997 Tentang pajak daerah dan retribusi daerah dan Peraturan Pemerintah nomor 69 tahun 2010 tentang tata cara pemberian dan pemanfaatan insentif pemungutan pajak daerah dan retribusi daerah.

Menurut Undang-Undang Republik Indonesia nomor 28 tahun 2009 (2011: 25) pajak restoran adalah pelayanan yang disediakan Restoran meliputi pelayanan penjualan makanan dan atau minuman yang dikonsumsi oleh pembeli, baik di konsumsi ditempat pelayanan maupun ditempat lain.

Menurut Peraturan Darah Kota Banjarbaru nomor 65 tahun 2017, Peraturan Walikota (PERWALI) tentang perubahan atas Peraturan Walikota nomor 77 tahun 2016 tentang Petunjuk Pelaksanaan Pelaksanaan Pemungutan Pajak Restoran :

1. Restoran

2. Rumah makan

3. Kafetarian

4. Kantin

5. Warung

6. Depot

7. Bar

8. Pujasera / foodcourt

9. Took roti / bakery

10. Jasa boga / catering

Menurut Siahaan Pahala Mariot (2011 : 272-273) dalam pungutan pajak restoran terdapat beberapa terminology yaitu :

1. Restoran adalah tempat menyantap makanan dan atau minuman yang disediakan dengan dipungut bayaran, tidak termasuk jasa boga dan catering.

2. Pengusaha restoran adalah orang pribadi atau badan dalam bentuk apapun, yang dalam lingkungan perusahaan atau pekerjaannya melakukan usaha dibidang rumah makan.

3. Pembayan adalah jumlah yang diterima atau seharusnya diterima sebagai imbalan atas penyerahan barang atau pelayanan, 
sebagai pembayaran kepada pemilik rumah makan.

4. Bon penjualan adalah bukti pembayaran atas pembelian makanan dan minuman kepada subyek pajak.

\section{METODELOGI PENELITIAN Rancangan Penelitian}

Penelitian ini termasuk dalam kategori penelitian asosiatif kausal dengan menggunakan pendekatan kuantitatif. Penelitian asosiatif kausal adalah penelitian yang bertujuan untuk mengetahui pengaruh antara dua variabel atau lebih. Penelitian ini akan menjelaskan hubungan mempengaruhi dan dipengaruhi dari variabelvariabel yang akan diteliti, yaitu variabel laporan, variabel kesadaran wajib pajak dan varaibel sosialisasi terhadap variabel Pendapatan Asli Daerah di Kota Banjarbaru.

\section{Jenis dan Sumber Data Penelitian}

\section{Jenis Data}

Jenis data yang digunakan dalam penelitian ini adalah data kuantitatif. Data kuantitatif merupakan data yang memenuhi kaidah ilmiah yaitu kongkrit, obyektif, rasional, terukur, dan sistematis yang berbentuk angka-angka atau satuan hitung menggunakan statistik (Sugiyono, 2013). Penelitian ini menggunakan data jumlah wajib pajak restoran dan jumlah penerimaan pajak restoran yang diperoleh dari Badan Pengelolaan Pajak dan Retribusi Daerah (BPPRD) Kota Banjarbaru.

\section{Sumber Data}

Sumber data yang diperlukan dalam penyusunan hasil penelitian ini terdiri dari dua jenis yaitu:

a. Data primer merupakan sumber data yang langsung diberikan kepada pengumpul data (Sugiyono, 2013). Data primer didapat dari sumber pertama, baik dari individu atau perorangan. Dalam penelitian ini sumber data yang digunakan adalah wajib pajak sebagai responden yang dipilih secara acak. Data primer yang dibutuhkan adalah data yang terkait dengan variabel yang digunakan.

b. Data sekunder merupakan sumber yang tidak secara langsung memberikan data kepada pengumpul data, semisal lewat orang lain atau dokumen (Sugiyono,
2014). Data sekunder bisa diambil dari catatan atau sumber lain yang telah ada dan yang sudah diolah oleh pihak ketiga secara berkala (time series) untuk melihat perkembangan objek penelitian selama periode tertentu. Dalam penelitian ini sumber data sekunder yaitu dokumen Realisasi Anggaran Pendapatan dan Belanja Daerah (APBD) Pemerintah Kota Banjarabru dengan periode pengamatan mulai dari tahun 2015 sampai tahun 2018.

\section{Populasi dan Sampel}

\section{Populasi}

Populasi merupakan gabungan dari seluruh elemen yang berbentuk peristiwa, hal atau orang yang memiliki karakteristik yang serupa menjadi pusat perhatian seorang peneliti, karena itu dipandang sebagai sebuah semesta penelitian (Mulyadi, 2016). Dalam penelitian ini yang menjadi populasi adalah wajib pajak restoran yang terdaftar dan mempunyai Nomor Pokok Wajib Pajak Daerah (NPWPD) dari Badan Pengelolaan Pajak dan Retribusi Daerah (BPPRD) Kota Banjarbaru tahun 2018 sejumlah 392 wajib pajak.

\section{Sampel}

Sampel Sampel adalah bagian dari populasi yang dijadikan sebagai objek penelitian, dengan kata lain sampel sebagai wakil dari populasi. Dalam pengambilan sampel yang perlu diperhatikan adalah bahwa karakteristik yang ada dalam populasi harus terwakili oleh sampel. Dengan pertimbangan akademik dan non akademik, populasi dapat diwakili oleh sebagian anggotanya yang disebut sampel.

Berdasarkan perhitungan rumus slovin, maka dalam penelitian ini adalah 79.67 dibulatkan menjadi 80 responden. Teknik pengambilan sampel dalam penelitian ini menggunakan teknik Probability Sampling.

\section{Teknik Pengumpulan Data}

Dalam penulisan tesis ini penulis mengumpulkan data dengan metode sebagai berikut:

1. Survey

Pengumpulan informasi yang 
memungkinkan analisis mempelajari sikapsikap, keyakinan, perilaku, dan karakteristik responden (Sugiyono, 2016). Alat pengambil data yang digunakan penelitian ini adalah dengan menggunakan kuesioner. Kuesioner yang diberikan kepada responden berisi pertanyaan tentang pengetahuan wajib pajak, tingkat kepuasan wajib pajak dengan kualitas pelayanan pembayaran pajak, respon wajib pajak dengan adanya pemeriksaan pajak dan kepatuhan wajib pajak dalam membayar dan melaporkan pajak restoran di Kota Banjarbaru.

2. Studi literatur

Adalah cara yang dipakai untuk menghimpun data-data atau sumber-sumber yang berhubungan dengan topik yang diangkat dalam suatu penelitian. Studi literatur bisa didapat dari berbagai sumber, jurnal, buku, dokumentasi, internet dan pustaka (Sugiyono, 2016). Pengumpulan data dilakukan ke instansi-instansi terkait yaitu Badan Pengelolaan Pajak dan Retribusi Daerah (BPPRD) Kota Banjarbaru. Data yang berkaitan dengan penelitian ini seperti data kondisi geografis Kota Banjarbaru, data jumlah wajib pajak restoran, data jumlah penerimaan pajak restoran dan data pajak daerah Kota Banjarbaru.

3. Wawancara

Metode pengumpulan data dengan mengadakan tanya jawab langsung dengan meminta penjelasan kepada pihak-pihak terkait yang mengetahui persoalan dari objek yang sedang diteliti. dalam penelitian ini, penulis melakukan wawancara dengan berbagai Bidang di Badan Pengelolaan Pajak dan Retribusi Daerah Kota Banjarbaru (Roy Paul Nelson, Jurnalistik 2009).

4. Kuesioner

Menurut Ulum dan Juanda (2016:96) kuesioner merupakan metode pengumpulan data dengan cara membagi daftar pertanyaan/pernyataan kepeda responden. Data yang akan diperoleh adalah data mengenai tingkat kepatuhan wajib pajak terhadap efektivitas pemungutan pajak restoran.
Menurut Bahri dan Zamzam (2014:53), instrument penelitian adalah kegiatan yang digunakan peneliti untuk mendapatkan informasi dari responden yang berwujud kuesioner yang berisi tentang sejumlah pertanyaan. Angket tersebut berisi pertanyaan seputar kepatuhan wajib pajak dan efektifitas pemungutan pajak restoran yang nantinya kuesioner tersebut akan disebarkan secara random sampling kepada 80 wajib pajak di Kota Banjarbaru. Penelitian ini menggunakan kuesioner yang dibuat secara tersusun berdasarkan tujuan penelitian. Kuesioner penelitian ini terbagi atas beberapa bagian. Bagian pertama kuesioner adalah tentang data demografi responden meliputi data umur, jenis kelamin, pendidikan dan jenis usaha restoran. Bagian kedua adalah persepsi responden mengenai pengetahuan pajak, kualitas pelayanan, pemeriksaan pajak dan kepatuhan wajib pajak dalam membayar pajak restoran di Kota Banjarbaru.

Skala pengukuran yang digunakan dalam penelitian ini adalah Skala Likert. Skala Likert digunakan untuk mengukur sikap, pendapat, dan perspeksi seseorang atau sekelompok orang (Sugiyono, 2016). Dalam mengukur variabelvariabel yang diuji dalam penelitian, setiap jawaban kuesioner akan diberi skor. Skor yang digunakan untuk tiap item Skala Likert dijelaskan di Tabel 4.1 berikut:

\section{Skala Pengukuran Instrumen Penelitian}

\begin{tabular}{|c|l|c|}
\hline No & \multicolumn{1}{|c|}{ Skala } & Skor \\
\hline 1 & Sangat Setuju & 5 \\
\hline 2 & Setuju & 4 \\
\hline 3 & Kurang Setuju & 3 \\
\hline 4 & Tidak Setuju & 2 \\
\hline 5 & Sangat Tidak Setuju & 1 \\
\hline
\end{tabular}

\section{Teknik Analisis Data}

Metode analisis penelitian ini terdiri analisis deskriftif dan analisis inferensial. Analisis deskriftif dalam penelitian ini digunakan untuk mengukur variabel yang ada, sedangkan analisis inferensial digunakan untuk menarik kesimpulan populasi dari informasi sampel yang ada. Untuk analisis inferensial dilakukan beberapa uji, diantaranya yaitu:

1. Uji Instrumen

1) Uji Validitas 
Validitas adalah suatu indeks yang menunjukkan bahwa instrument yang dipakai benar-benar mengukur apa yang hendak di ukur. Reliabilitas adalah indeks yang menunjukkan keterandalan atau dapat dipercaya dari suatu alat ukur. (Sugiono, 2012).

Uji validitas dilakukan untuk mengetahui apakah instrument yang digunakan sudah tepat mengukur apa yang seharusnya diukur atau belum, sehingga dapat dikatakan bahwa semakin tinggi validitas suatu test, maka alat test tersebut akan semakin tepat mengenai sasaran.

Menurut Sugiono (2012), bila korelasi tiap faktor positif dan besarnya $>0,3$ maka faktor tersebut merupakan construct yang kuat, demikian pula sebaliknya, jika $<0,3$ maka dikatakan tidak valid.

2) Uji Reliabilitas

Untuk uji reliabilitas digunakan metode belah dua (Split Half Method) dari Spearman Brown. Metode belah dua ini dilakukan dengan cara membagi instrument menjadi dua belahan, bisa ganjil-genap dan bisa pula belahan pertama dan kedua dengan rumus:

Keterangan ;

$$
r_{11}=\frac{2 r_{b}}{1+r_{b}}
$$
$r_{11}=$ reliabilitas internal seluruh

$r_{b}=$ korelasi product moment antara belahan kesatu dan kedua kemudian dikorelasikan

Jika $r_{x y}>0,6$, maka instrument tersebut dikatakan reliabel. Demikian bila

2. Pengujian Asumsi Klasik

1) Uji Normalitas

Uji normalitas, untuk mengetahui apakah residual yang dihasilkan oleh model analisis regresi berdistribusi normal atau tidak. Untuk mendeteksi apakah residual berdistribusi normal atau tidak, dapat dilihat melalui uji Klogmorov Smirnov. Residual dinyatakan normal apabila probabilitas dari uji Klogmorov Smirnov bernilai lebih besar dari level of significant (alpha $=5 \%$ ).

2) Uji Multikolonieritas

Uji ini diperlukan untuk mengetahui apakah ada tidaknya variabel independen yang memiliki kemiripan dengan variabel independen lain dalam satu model (Nugroho 2005 dalam Ardhani 2011). Selain itu deteksi terhadap multikoliniearitas juga bertujuan untuk menghindari bisa dalam proses pengambilan keputusan mengenai pengaruh pada uji parsial masing-masing variabel independen terhadap variabel dependen. Deteksi multikolinieritas pada suatu model dapat diketahui jika nilai Variance Inflation Factor (VIF) tidak lebih dari 10 dan nilai Tolerance tidak kurang dari 0,1, maka model tersebut dapat dikatakan terbebas dari multikolinieritas, sedangkan VIF = 1/Tolerance, jika VIF $=10$ maka Tolerance $=1 / 10=0,1$.

3) Uji Heteroskedastisitas

Uji Heteroskedastisitas, digunakan untuk mengetahui apakah residual memiliki ragam yang homogeny atau tidak. Pada analisis regresi linier diharapkan residual memiliki ragam yang homogeny. Pengujian asumsi heteroskedastisitas dapat diuji menggunakan Glejser Test. Kriteria pengujian menyatakan bahwa apabila probabilitas dari uji Glejser Test bernilai lebih besar dari level significant (alpha $=$ 5\%) maka residual dinyatakan memiliki ragam yang homogen.

3. Regresi Linear Berganda

Analisis regresi Linear berganda adalah hubungan secara linear antara dua atau lebih variabel dependen (X1, X2, X3) dengan variabel depeden (Y). Analisis ini memprediksi nilai dari variabel depeden apabila nilai variabel independen mengalami kenaikan atau penurunan dan untuk mengetahui arah hubungan antara variabelindependen dengan variabel dependen apakah masing-masing variabel independen berhubungan positif atau negatif (priyanto, 2010).

Analisis regresi linear berganda dalam penelitian ini digunakan untuk menghitung besarnya pengaruh variabel independen pajak restoran terhadap variabel dependen Pajak Asli Daerah. Untuk menguji hipotesis dalam penelitian ini digunakan model berikut :

$$
Y=a+b_{1} X_{1}+b_{2} X_{2}+b_{3} X_{3}=e
$$


rata-rata sampel terhadap nilai yang diuji.

Dimana :

$\begin{array}{rlrl}\mathrm{Y} & = & \text { Pendapatan Asli Daerah } \\ \mathrm{A} & = & \text { Konstanta, besar nilai Y jika X } \\ & =0 \\ \text { b1-b2-b3 }= & \text { Koefisien arah regresi, yang } \\ & \text { menyatakan perubahan nilai Y } \\ & \text { apabila terjadi perubahan nilai } \\ & \mathrm{X} \\ \mathrm{X} 1 & = \\ \mathrm{X} 2 & \text { Laporan wajib pajak } \\ \mathrm{X} 3 \quad & \text { Kesadaran wajib pajak } \\ = & \text { Sosialisasi sistem } \\ & \text { Besarnya konstanta dalam a dan }\end{array}$
besarnya koefisien regresi masing-masing variabel independen yang ditujukan X1, X2 dan X3. Analisis regresi dilakukan untuk mengetahui seberapa besar hubungan antara variabel independen dengan variabel depedennya.

4. Pengujian Hipotesis

1) Uji F (Uji Simultan)

Pengujian serentak digunakan untuk mengetahui apakah secara simultan koefisien variabel bebas mempunyai pengaruh nyata atau tidak terhadap variabel terikat (Sugiono, 2005:250), Pengujian melalui uji $\mathrm{F}$ dengan jalan membandingkan $\mathrm{F}$ hitung dengan probabilitas $=0,005$ yaitu taraf nyata digunakan sebesar $5 \%(0,05)$ dengan derajat kebebasan $\mathrm{df}=(\mathrm{k}-1)(\mathrm{n}-\mathrm{k}-1)$, maka bila $\mathrm{F}$ hitung $>(0,005)$. Kondisi ini menunjukan seluruh variabel bebas secara serentak atau simultan mampu memberikan penjelasan terhadap variasi pada variabel tergantungnya, atau dengan kata lain bahwa model analisis yang digunakan adalah model hipotesa.

2) Uji t ( Uji Parsial)

Uji $t$ digunakan untuk menguji signifikansi konstanta dari variabel bebas secara varsial atau individu terhadap variabel terikat. Pengujian ini dilakukan dengan membandingkan nilai $t$ hitung dengan nilai $t$ tabal. Apabila $t$ dihitung $>t$ tetabel dengan signifikan dibawah 0,05 (5\%), maka secara parsial atau individual variabel bebas berhubungan signifikan terhadap variabel terikat, begitu juga sebaliknya. Zikmund (dalam Istijanto, 2006:100) menjelaskan Uji t merupakan uji statistik terhadap signifikan tidaknya nilai
Uji signifikansi koefesien korelasi dimaksud untuk menguji apakah besarnya atau kuatnya hubungan antar variabel yang diuji sama dengan nol. Apabila besarnya hubungan sama dengan nol, hal tersebut menunjukan bahwa hubungan antar variabel sangat lemah dan tidak berarti. Dan sebaliknya apabila hubungan antar variabel secara signifikan berbeda dengan nol, maka hubungan tersebut kuat.

3) Koefisien Determinasi $(\Delta \mathrm{R})^{2}$

Delta koefisien determinasi $(\Delta \mathrm{R})^{2}$ mengukur seberapa jauh kemampuan model dalam menerangkan variabelvariabel dependen. Penggunaan delta koefisien determinasi menghasilkan nilai yang relatif kecil daripada nilai koefisien determinasi $(\mathrm{R})^{2}$. Nilai delta koefisien determinasi $(\Delta \mathrm{R})^{2}$ yang kecil disebabkan adanya varians error yang semakin besar. Dengan demikian, semakin besar nilai delta koefisien determinasi $(\Delta \mathrm{R})^{2}$, maka variabel independen mampu memprediksi variasi variabel dependen (Sugiono, 2012).

\section{HASIL DAN PEMBAHASAN \\ Hasil Penelitian \\ Uji Instrumen}

\section{Uji Validitas}

Uji Validitas adalah prosedur untuk memastikan apakah kuesioner yang akan dipakai untuk mengukur variabel penelitian valid atau tidak. Kuesioner dapat dikatakan valid jika pernyataan pada kuesioner mampu mengungkapkan sesuatu yang diukur oleh kuesioner tersebut. Untuk mengetahui item pernyataan itu valid dengan melihat nilai Corrected Item Total Corelation. Apabila item pernyataan mempunyai $r$ hitung $>$ dari $r$ tabel maka dapat dikatakan valid. Pada penelitian ini terdapat jumlah sampel $(\mathrm{n})=80$ responden dan besarnya df dapat dihitung 80-2 $=78$ dengan $\mathrm{df}=78$ dan alpha $=0,05$ didapat $\mathrm{r}_{\text {tabel }}=0,2199$. Jadi, item pernyataan yang valid mempunyai $r_{\text {hitung }}$ lebih besar dari $\mathrm{r}_{\text {tabel. }}$. Adapun hasil uji validitas datadalam penelitian ini dapat dilihat pada masingmasing tabelberikut: 
Hasil Uji Validitas Variabel Laporan $\left(\mathbf{X}_{1}\right)$

\begin{tabular}{|c|c|c|}
\hline No Item & Tingkat Validitas & Keterangan \\
\hline Item_1 & 0,757 & Valid \\
\hline Item_2 & 0,856 & Valid \\
\hline Item_3 & 0,889 & Valid \\
\hline Item_4 & 0,814 & Valid \\
\hline Item_5 & 0,889 & Valid \\
\hline
\end{tabular}

Berdasarkan data tabel di atas menunjukkan bahwa tingkat validitas untuk setiap item pada variabel laporan $\left(\mathrm{X}_{1}\right)$ melibih $r_{\text {tabel }}$ yaitu 0,2199, dengan demikian semua pernyataan dinyatakan valid.

Selanjutnya hasil uji validitas untuk variabel kesadaran wajib pajak $\left(\mathrm{X}_{2}\right)$ sebagai berikut:

\section{Hasil Uji Validitas Variabel Kesadaran Wajib Pajak $\left(\mathrm{X}_{2}\right)$}

\begin{tabular}{|c|c|c|}
\hline No Item & Tingkat Validitas & Keterangan \\
\hline Item_1 & 0,617 & Valid \\
\hline Item_2 & 0,814 & Valid \\
\hline Item_3 & 0,800 & Valid \\
\hline Item_4 & 0,690 & Valid \\
\hline Item_5 & 0,414 & Valid \\
\hline
\end{tabular}

Berdasarkan tabel di atas menunjukkan bahwa item pernyataan dalam variabel kesadaran wajib pajak $\left(\mathrm{X}_{2}\right)$ semua dinyatakan valid karena nilai tingkat validitas menunjukkan lebih besar dari $\mathrm{r}_{\text {tabel }}$.

Selanjutnya uji validitas variabel sosialisasi $\left(\mathrm{X}_{3}\right)$ dengan hasil sebagai berikut:

\section{Hasil Uji Validitas Variabel Sosialisasi} $\left(\mathrm{X}_{3}\right)$

\begin{tabular}{|c|c|c|}
\hline No Item & Tingkat Validitas & Keterangan \\
\hline Item_1 & 0,865 & Valid \\
\hline Item_2 & 0,818 & Valid \\
\hline Item_3 & 0,860 & Valid \\
\hline Item_4 & 0,814 & Valid \\
\hline Item_5 & 0,845 & Valid \\
\hline
\end{tabular}

Dari tabel diatas menunjukkan bahwa variabel sosialisasi $\left(\mathrm{X}_{3}\right)$ semua item pernyataannya dinyatakan valid karena nilai validitas di atas $r_{\text {tabel }}$ yaitu $0,2199$.

Uji validitas variabel pendapatan asli daerah (Y) diperoleh hasil sebagai berikut:

\section{Hasil Uji Validitas Variabel Pendapatan} Asli Daerah (Y)

\begin{tabular}{|l|l|l|} 
No Item & Tingkat Validitas & Keterangan \\
\hline
\end{tabular}

\begin{tabular}{|c|c|c|}
\hline Item_1 & 0,894 & Valid \\
\hline Item_2 & 0,841 & Valid \\
\hline Item_3 & 0,894 & Valid \\
\hline Item_4 & 0,596 & Valid \\
\hline Item_5 & 0,717 & Valid \\
\hline
\end{tabular}

Berdasarkan uji validitas pada tabel diatas menunjukkan bahwa nilai validitas variabel pendapatan asli daerah (Y) diatas nilai $r_{\text {tabel }}$ yaitu 0,2199, sehingga hal ini menyatakan semua item pernyataannya dinyatakan valid.

\section{Uji Reliabilitas}

Konsep reliabilitas dapat dipahami melalui ide dasar konsep tersebut yaitu konsistensi. Peneliti dapat mengevaluasi instrumen penelitian berdasarkan perspektif dan teknik yang berbeda, tetapi pertanyaan mendasar untuk mengukur reliabilitas data adalah bagaimana konsistensi data yang dikumpulkan. Pengukuran reliabilitas menggunakan indeks numerik yang disebut dengankoefisien.

Uji reliabilitas merupakan alat ukur untuk mengukur suatu kuesioner yang merupakan indikator dari variabel. Suatu kuesioner dikatakan reliabel jika jawaban dari responden itu stabil dari waktu ke waktu. Kriteria suatu instrumen penelitian dikatakan reliabel jika dengan menggunakan uji statistik Cronbach Alpha $(\alpha)$, koefisien reliabilitas $>0,60$.

\section{Hasil Uji Reliabilitas}

\begin{tabular}{|l|c|c|}
\hline \multicolumn{1}{|c|}{ Variabel } & $\begin{array}{c}\text { Nilai Alpha } \\
\text { Cronbach's }\end{array}$ & Kriteria \\
\hline Laporan $\left(\mathrm{X}_{1}\right)$ & 0,884 & Reliabel \\
\hline Wajib pajak Restoran $\left(\mathrm{X}_{2}\right)$ & 0,666 & Reliabel \\
\hline Sosialisasi $\left(\mathrm{X}_{3}\right)$ & 0,883 & Reliabel \\
\hline Pendapatan Asli Daerah $(\mathrm{Y})$ & 0,839 & Reliabel \\
\hline
\end{tabular}

Hasil uji realibitas didapatkan dari semua hasil variabel menghasilkan nilai alpha cronbanch's >0.6. sehingga dapat disimpulkan semua instrument dalam penelitian ini reliable.

\section{Uji Asumsi Klasik}

\section{Uji Normalitas}

Uji normalitas dilakukan untuk melihat apakah nilai residual terdistribusi normal atau tidak. Untuk lebih memastikan apakah data residual terdistribusi secara normal atau tidak, maka uji statistik yang dapat 
dilakukan yaitu pengujian one sample kolmogorov-smirnov. Uji ini digunakan untuk menghasilkan angka yang lebih detail, apakah suatu persamaan regresi yang akan dipakai lolos normalitas. Suatu persamaan regresi dikatakan lolos normalitas apabila nilai signifikansi uji Kolmogorov-Smirnov lebih besar dari 0,05. Hasil pengujian normalitas yang dilakukan menunjukkan bahwa data berdistribusi normal. Hal ini ditunjukkan dengan nilai signifikansi sebesar $>0,05$.

Hasil uji normalitas menggunakan metode Kolomogrov Smirnov didapatkan hasil signifikan dari uji normalitas sebesar 0,037 dimana hasil tersebut lebih kecil dari taraf signifikansi 0,05 . Sehingga dapat disimpulkan bahwa uji normalitas pada penelitian ini tidak terdistrubusi normal.

\section{Uji Multikolinieritas}

Uji multikolinieritas bertujuan untuk menguji apakah dalam model regresi ditemukan adanya korelasi antara variabel bebas (independen). Jika variabel independen saling berkolerasi, maka variabel-variabel tidak ortogonal. Model regresi yang baik adalah yang bebas dari multikolinieritas. Nilai cut off yang umum dipakai untuk menunjukan adanya multikolinieritas nilai tolerance $>0,10$ atau nilai VIF $<10$.

Berdasarkan hasil pengolahan data variance inflation menunjukan bahwa nilai VIF $<10$ dan nilai tolerance $>0,1$ sehingga dapat disimpulkan bahwa model regresi tidak terjadi masalah multikolinearitas.

\section{Uji Heterokedastisitas (Uji Glejser)}

Uji heteroskedastisitas bertujuan untuk menguji apakah dalam model regresi terjadi ketidaksamaan variance dari residual satu pengamatan ke pengamatan yang lain. Jika varian dari residual satu pengamatan ke pengamatan lain tetap, maka disebut homoskedastistas dan jika berbeda disebut heteroskedastistas.

Dari hasil uji heteroskedastisitas menggunakan Uji Glejser menunjukkan bahwa nilai signifikansi uji t ketiga variabel independen dengan Absolut Residual (ABSRES) lebih dari 0,05, sehingga hal ini dapat disimpulkan bahwa pada model regresi tidak ada masalah heteroskedastisitas.

\section{Uji Autokorelasi}

Dasar pengambilan keputusan dalam uji autokorelasi Durbin Watson. Metode pengujian yang seringdigunakan dalam Tesis Kuantitatif adalah dengan uji durbinwatson (uji DW) dengan ketentuan atau dasar pengambilan keputusan sebagai berikut :

a. Jika d (durbin Watson) lebih kecil dari dL atau lebih besar dari (4-dL) maka hipotesis nol ditolak, yang berarti terdapat autokorelasi.

b. Jika d (durbin Watson) terletak antara $\mathrm{dU}$ dan (4-dU), maka hipotesis nol diterima, yang berarti tidak ada autokorelasi.

c. Jika d (durbin Watson) terletak antara dL dan dU atau diantara (4-dU) dan (4dL), maka tidak menghasilkan kesimpulan yang pasti.

Berdasarkan hasil table uji autokorelasi diketahui untuk nilai Durbin Watson = 1,873, selanjutnya dibandingkan dengan nilai table signifikansi $5 \%(0,05)$ dengan jumlah sampel 80 dan jumlah variabel independent adalah 3 atau $\mathrm{K}=3$, sehingga didapatkan hasil $\mathrm{dL}=1,5600$ dan $\mathrm{dU}=1,7153$. Dengan ini maka di dapat 4-dU $=4-1,7153=2,2847$ kemudian untuk 4-dL $=4-1,5600=2,440$. Karena nilai $\mathrm{DW}=$ 1,873 berada antara dU dan (4-dU), maka hipotesis nol diterima, yang berarti tidak ada autokorelasi.

Untuk membuktikan hipotesis yang telah dikemukakan, peneliti menggunakan metode regresi linier berganda untuk mengetahui pengaruh antara variabel laporan, variabel kesadaran wajib pajak dan variabel sosialisasi terhadap variabel pendapatan asli daerah, dengan persamaan sebagai berikut:

\section{Analisis Regresi Linier Berganda}

Setelah dilakukan uji validitas dan reliabilitas data dapat diperoleh kesimpulan bahwa model telah dapat digunakan untuk melakukan pengujian analisis regresi linear berganda. Berdasarkan hasil pengolahan data penelitian yang telah dilakukan ditunjukan pada lampiran (coefficients). Berdasarkan hasil uji regresi linear berganda yang telah dilakukan dengan menggunakan SPSS maka diperoleh ringkasan hasil uji regresi sebagai berikut : 
Analisis Regresi LinearBerganda Coefficients $^{\mathrm{a}}$

\begin{tabular}{|c|c|c|c|c|c|}
\hline \multirow[t]{2}{*}{ Model } & \multicolumn{2}{|c|}{$\begin{array}{l}\text { Unstandardize } \\
\text { d Coefficients }\end{array}$} & \multirow{2}{*}{$\begin{array}{c}\begin{array}{c}\text { Standardize } \\
\mathrm{d} \\
\text { Coefficient } \\
\mathrm{s}\end{array} \\
\text { Beta }\end{array}$} & \multirow[t]{2}{*}{$\mathrm{t}$} & \multirow[t]{2}{*}{ Sig. } \\
\hline & B & $\begin{array}{l}\text { Std. } \\
\text { Error }\end{array}$ & & & \\
\hline (Constant & $\begin{array}{r}- \\
3.20 \\
1\end{array}$ & 1.153 & & $2.777^{-}$ & $\begin{array}{r}.00 \\
7\end{array}$ \\
\hline $\begin{array}{l}\text { Laporan } \\
\text { X1 }\end{array}$ & .086 & .040 & .085 & 2.170 & $\begin{array}{r}.03 \\
3\end{array}$ \\
\hline $\begin{array}{l}1 \begin{array}{l}\text { Kesadara } \\
\text { n WAJIB }\end{array} \\
\text { PAJAK } \\
\text { Restoran } \\
\text { X2 }\end{array}$ & .103 & .051 & .080 & 2.019 & $\begin{array}{r}.04 \\
7\end{array}$ \\
\hline $\begin{array}{l}\text { Sosialisa } \\
\text { si X3 }\end{array}$ & .962 & .041 & .915 & $\begin{array}{r}23.28 \\
4\end{array}$ & $\begin{array}{r}.00 \\
0 \\
\end{array}$ \\
\hline
\end{tabular}

a. Dependent Variable: Pendapatan Asli Daerah Y

\section{Hasil Uji F}

\begin{tabular}{|c|c|c|c|c|c|}
\hline \multicolumn{6}{|c|}{ ANOVA $^{a}$} \\
\hline Model & $\begin{array}{l}\text { Sum of } \\
\text { Squares }\end{array}$ & $\mathrm{df}$ & $\begin{array}{c}\text { Mean } \\
\text { Square }\end{array}$ & $\mathrm{F}$ & Sig. \\
\hline Regression & 1506.853 & 3 & 502.284 & 197.692 & $.000^{\mathrm{b}}$ \\
\hline 1 Residual & 193.097 & 76 & 2.541 & & \\
\hline Total & 1699.950 & 79 & & & \\
\hline
\end{tabular}

a. Dependent Variable: Pendapatan Asli Daerah Y

b. Predictors: (Constant), Sosialisasi X3, Laporan X1,

Kesadaran WAJIB PAJAK Restoran X2

$$
\begin{aligned}
& Y=a+b_{1} X_{1}+b_{2} X_{2}+b_{3} X_{3}+e \\
& Y=-3,201+0,086 X_{1}+0,103 X_{2}+0,962 X_{3} \\
& +e
\end{aligned}
$$

Penjelasan:

1. Konstanta sebesar -3,201; artinya jika variabel laporan, variabel kesadaran wajib pajak dan variabel sosi

2. alisasi nilainya 0 (nol), maka variabel pendapatan asli daerah nilainya sebesar 3,201 .

3. Koefisien regresi variabel laporan sebesar 0,086; jika variabel laporan ditingkatkan satu satuan, maka variabel pendapatan asli daerah akan mengalami peningkatan sebesar 0,086 dengan asumsi variabel independen lainnya bernilai tetap.

4. Koefisien regresi variabel kesadaran wajib pajak sebesar 0,103; artinya jika variabel kesadaran wajib pajak ditingkatkan satu satuan, maka variabel pendapatan asli daerah akan mengalami peningkatan sebesar 0,103, dengan asumsi variabel independen lainnya bernilai tetap.

5. Koefisien regresi variabel sosialisasi sebesar 0,962; artinya variabel sosialisasi terhadap variabel pendapatan asli daerah. Jika variabel sosialisasi ditingkatkan, maka variabel pendapatan asli daerah akan mengalami peningkatan sebesar 0,962 dengan asumsi variabel independen lainnya bernilai tetap.

\section{Hasil Uji Hipotesis}

\section{Uji F (Uji Simultan)}

Pengujian signifikan bertujuan untuk mengetahui signifikansi korelasi Laporan (X1), Kesadaran wajib pajak (X2), Sosialisasi (X3) yang dilakukan pada studi pada restoran yang berada di Kota Banjarbaru.

Uji $\mathrm{F}$ digunakan untuk mengetahui apakah variabel independen secara bersamasama berpengaruh terhadap variabel dependen atau tidak. Dengan menggunakan signifikansi 0,05 dengan df 1 (jumlah variabel -1$)$ atau $4-1=3$ dan df $2(n-k-$ 1) atau $80-3-1=76$, maka diperoleh nilai untuk $F$ tabel sebesar 2,725. Berdasarkan hasil pengujian dengan SPSS versi 20 diperoleh $F_{\text {hitung }}$ adalah 197,692 Karena $F_{\text {hitung }}>F_{\text {tabel }}(197,692>2,725)$, dan signifikansi sebesar $0,000<0,05$, maka Ho ditolak dan $\mathrm{Ha}$ diterima, artinya bahwa variabel laporan, variabel kesadaran wajib pajak dan variabel sosialisasi secara bersama-sama berpengaruh signifikan terhadap variabel pendapatan asli daerah.

\section{Uji t ( Uji Parsial)}

Uji $t$ menunjukan seberapa jauh pengaruh satu variabel independen secara individual mampu memerankan variasi variabel dependen. Untuk mengetahui variabel yang berpengaruh signifikan secara parsial dilakukan pengujian koefisien regresi dengan menggunakan statistik Uji t. Penentuan hasil pengujian (penerimaan/ 
penolakan H0) dapat dilakukan dengan membandingkan $t_{\text {hitung }}$ dengan $t_{\text {tabel }}$.

Untuk membuat kesimpulan menerima atau menolak Ho, terlebih dahulu harus ditentukan nilai $t_{\text {tabel, dimana dalam }}$ menentukan $t_{\text {tabel }}$ yang digunakan di dasarkan pada besarnya degree of freeedom (df) dan tingkat signifikansi yang digunakan. Tingkat signifikansi yang digunakan sebesar 5\%. Tabel distribusi $\mathrm{t}$ dicari pada $\mathrm{a}=5 \%: 2=2,5 \%$ (uji 2 sisi) dengan derajat kebebasan (df) n - k -1 (80 $3-1=76$ ) maka diperoleh nilai $t_{\text {tabel }}$ sebesar 1,665. Hasil pengujian pengaruh setiap variabel independent terhadap variabel dependent sebagai berikut:

1) Pengaruh laporan terhadap pendapatan asli daerah

Berdasarkan output hasil uji $\mathrm{t}$ pada tabel 5.15 diketahui nilai thitung adalah sebesar 2,170. Dengan membandingkan hasil nilai $t_{\text {hitung }}>\mathrm{t}_{\text {tabel }}$ $(2,170>1,665)$ maka thitung yang diperoleh lebih besar dari nilai $t_{\text {tabel }}$ begitu juga dengan nilai signifikansinya diperoleh $0,033<0,05$ sehingga Ho ditolak. Dengan demikian dapat disimpulkan bahwa variabel laporan berpengaruh signifikan terhadap pendapatan asli daerah.

2) Pengaruh kesadaran wajib pajak terhadap pendapatan asli daerah

Berdasarkan output hasil uji t tabel 5.15 diketahui nilai t-hitung untuk variabel kesadaran wajib pajak sebesar 2,019. Dengan membandingkan thitung < $t_{\text {tabel }}(2,019>1,665)$ maka thitung yang diperoleh lebih besar dari nilai tabel dan nilai signifikasi sebesar $0,047<0,05$, sehingga Ho ditolak. Dengan demikian dapat disimpulkan bahwa variabel kesadaran wajib pajak berpengaruh terhadap pendapatan asli daerah.

3) Pengaruh sosialisasi terhadap pendapatan asli daerah

Sementara pengaruh sosialisasi berdasarkan output hasil uji t tabel 5.15 diketahui nilai $t_{\text {hitung }}$ untuk variabel sosialisasi sebesar 23,284. Dengan membandingkan hasil nilai $t_{\text {hitung }}>\mathrm{t}_{\text {tabel }}$ $(23,284>1,665)$ maka thitung yang diperoleh lebih besar dari nilai t-abel dan nilai signifikasin diperoleh $0,000<$ 0,05, sehingga Ho dtolak. Dengan demikian dapat disimpulkan bahwa variabel sosialisasi berpengaruh signifikan terhadap pendapatan asli daerah.

Berdasarkan ketiga pengujian di atas, maka dapat disimpulkan bahwa ketiga variabel independen (laporan, kesadaran wajib pajak dan sosialisasi) berpengaruh signifikan terhadap variabel dependen (pendapatan asli daerah).

\section{Analisis Koefisien Determinasi} Analisis Koefisien Determinasi Model Summary

\begin{tabular}{|l|r|r|r|r|}
\hline Model & $\mathrm{R}$ & $\begin{array}{c}\mathrm{R} \\
\text { Square }\end{array}$ & $\begin{array}{c}\text { Adjusted } \\
\text { R Square }\end{array}$ & $\begin{array}{c}\text { Std. Error of } \\
\text { the Estimate }\end{array}$ \\
\hline 1 & $.941^{\mathrm{a}}$ & .886 & .882 & 1.594 \\
\hline
\end{tabular}

a. Predictors: (Constant), Sosialisasi X3, Laporan X1, Kesadaran WAJIB PAJAK Restoran X2

Berdasarkan output dari hasil analisis regresi linier berganda sebagaimana tabel koefisien korelasi diperoleh nilai koefisien determinasi atau angka Adjusted $R$ Square sebesar 0,882 atau 88,2 \%. Hal ini menunjukan bahwa prosentase sumbangan pengaruh variabel yang diteliti (laporan, kesadaran wajib pajak dan sosialisasi) terhadap pendapatan asli daerah Kota Banjarbaru sebesar 88,2\% sedangkan sisanya dipengaruhi variabel yang tidak diteliti (variabel pengganggu).

\section{Pembahasan}

Pelaporan, kesadaran wajib pajak dan sosialisasi sistem berpengaruh simultan terhadap PAD Kota Banjarbaru

Berdasarkan hasil penelitian, menunjukan hasil bahwa variabel independen yakni variabel laporan $\left(\mathrm{X}_{1}\right)$, kesadaran wajib pajak $\left(\mathrm{X}_{2}\right)$ dan sosialisasi $\left.\mathrm{X}_{3}\right)$ secara bersama-sama berpengaruh terhadap pendapatan asli daerah (Y) di Kota Banjarbaru menunjukkan kriteria kuat. Hal ini di tunjukkan dari hasil pengujian dengan SPSS versi 20 diperoleh $F_{\text {hitung }}$ adalah 197,692 lebih besar dari $F_{\text {tabel }} 2,725$ artinya bahwa variabel laporan, variabel kesadaran wajib pajak dan variabel sosialisasi secara 
bersama-sama berpengaruh signifikan terhadap pendapatan asli daerah di Kota Banjarbaru.

Sementara nilai dari Adjusted $R$-Square menunjukkan bahwa ketiga variabel independent/ bebas yang terdiri dari variabel laporan, variabel kesadaran wajib pajak dan variabel sosialisasi secara simultan mempunyai pengaruh yang membuat pendapatan asli daerah meningkat atau menurun. Artinya secara bersama-sama variabel independent/ bebas yaitu variabel laporan, variabel kesadaran wajib pajak dan variabel sosialisasi memberikan kontribusi/ pengaruh sebesar $88,2 \%$ terhadap pendapatan asli daerah di Kota Banjarbaru.. Sisanya merupakan pengaruh faktor lain diluar ketiga variabel bebas yang diteliti.

Hasil penelitian menunjukan bahwa laporan, kesadaran wajib pajak dan sosialisasi berpengaruh terhadap pendapatan asli daerah. Hasil ini sesuai dengan pendapat Nugroho (2013) mengatakan bahwa keputusan wajib pajak dipengaruhi oleh laporan, kesadaran wajib pajak dan sosialisasi. Sedangkan faktor yang mempengaruhi prilaku wajib pajak dalam menyampaikan laporan pajak, salah satunya oleh faktor demografi. Salah satu faktor demografi adalah pendapatan wajib pajak yang paling sering dijadikan dasar untuk membayar pajak.

Pelaporan, kesadaran wajib pajak dan sosialisasi berpengaruh secara parsial terhadap pendapatan asli daerah Kota Banjarbaru

\section{Laporan berpengaruh terhadap} pendapatan asli daerah Kota Banjarbaru

Laporan merupakan bukti dokumen pertanggungjawaban atas sesuatu kegiatan yang telah dilaksanakan. Terkait dengan pembayaran pajak restoran, laporan pajak restoran merupakan dasar dalam pembayaran pajak restoran dalam satu periode ke depan. Sehingga dengan demikian, adanya laporan pajak restoran akan menjadi bukti bahwa ada penambahan terhadap pendapatan asli daerah Kota Banjarbaru.

Berdasarkan output hasil uji t diketahui nilai $t_{\text {hitung }}$ adalah sebesar 2,170. Dengan membandingkan hasil nilai $t_{\text {hitung }}>t_{\text {tabel }}(2,170>$ 1,665) maka thitung yang diperoleh lebih besar dari nilai $t_{\text {tabel }}$ begitu juga dengan nilai signifikansinya diperoleh $0,033<0,05$ sehingga
Ho ditolak. Dengan demikian dapat disimpulkan bahwa variabel laporan berpengaruh signifikan terhadap pendapatan asli daerah.

Berdasarkan analisis frekuensi tanggapan responden sebagaimana tabel $5.2 \mathrm{di}$ atas, terhadap pernyataan bahwa melakukan penghitungan dan rekapitulasi dibebankan pada wajib pajak, direspon dengan jawaban sangat setuju dan setuju masing-masing 21,25\% (17), responden menjawab kurang setuju sebanyak $11,25 \%$ (9), sementara $35,00 \%$ (28) responden menjawab tidak setuju dan $11,25 \%$ (9) responden menyatakan sangat tidak setuju. Terhadap pernyataan menyiapkan dan memiliki bukti transaksi dan laporan penjualan merupakan hal yang selalu diminta oleh petugas dalam pemeriksaan pajak, dijawab oleh para responden sebanyak $17,50 \%$ (14) responden menjawab sangat setuju, sebanyak 26,25\% (21) responden menjawab setuju, sebanyak $41,25 \%$ atau 33 responden menjawab kurang setuju, sementara $15,00 \%$ (12) responden menjawab tidak setuju.

Terhadap pernyataan melakukan pengisian formulir dalam melakukan pembayaran sesuai tarif pajak restoran, direspon oleh 16 responden atau 20,00\% dengan jawaban sangat setuju, sebanyak 18 responden atau $22,50 \%$ menjawab setuju begitu juga dengan jawaban kurang setuju dengan nilai yang sama. Sedangkan sebanyak 22 responden atau 27,50\% menjawab tidak setuju serta 6 responden atau 7,50\% menjawab sangat tidak setuju. Terhadap pernyataan adanya sanksi dan denda pajak apabila tidak melaporkan dan membayar pajak tepat waktu dijawab sangat setuju oleh sebanyak $18,75 \%$ atau 15 responden, sebanyak $30,00 \%$ (24) responden menjawab setuju, sebanyak $42,50 \%$ (34) menjawab kurang setuju, sedangkan yang menjawab tidak setuju ada $8,75 \%$ (7) responden. Sementara pernyataan melakukan perhitungan tunggakan pajak dan membuat laporan apabila telat dalam melakukan pembayaran pajak dinyatakan dengan jawaban sangat setuju oleh $17,50 \%$ (14) responden, sebanyak $27,50 \%$ (22) responden menyatakan setuju, sebanyak $38,75 \% \quad$ (31) responden menyatakan kurang setuju, dan sebanyak $15,00 \%$ atau 12 responden menyatakan tidak setuju serta sebanyak $1,25 \%$ atau 1 responden menyatakan sangat tidak setuju pada pernyataan tersebut. 
Hal ini sependapat dengan Nugroho (2013) yang mengatakan bahwa keputusan wajib pajak dipengaruhi oleh kewajiban dalam membuat laporan pajak. Dengan demikian, salah satu indikator seseorang sadar akan kewajiban membayar pajak maka harus membuat dan menyerahkan laporan pajak atau SPT, karena laporan tersebut sebagai dasar melakukan pembayaran pajak. Sehingga semakin banyak wajib pajak restoran di Kota Banjarbaru yang menyerahkan laporan pajaknya, maka semakin banyak wajib pajak restoran yang membayar pajak, maka semakin besar nilai pendapatan asli daerah Kota Banjarbaru dari sektor penerimaan pajak restoran.

\section{Kesadaran wajib pajak berpengaruh terhadap pendapatan asli daerah Kota Banjarbaru}

Kesadaran wajib pajak merupakan kondisi dimana Wajib Pajak mengetahui, mengakui menghargai dan menaati ketentuan perpajakan yang berlaku serta memiliki kesungguhan dan keinginan untuk memenuhi kewajiban pajaknya. Adanyanya kesadaran wajib pajak akan mempengaruhi kepatuhan seseorang dalam membayar pajak. Dengan demikian, semakin banyak wajib pajak restoran di Kota Banjarbaru yang sadar akan kewajibannya maka akan semakin banyak wajib pajak restoran yang membayar pajak, sehingga hal ini akan mempengaruhi nilai pendapatan asli daerah Kota Banjarbaru.

Berdasarkan output hasil uji $\mathrm{t}$ diketahui nilai t-hitung untuk variabel kesadaran wajib pajak sebesar 2,019. Dengan membandingkan thitung < $t_{\text {tabel }}(2,019>1,665)$ maka $t_{\text {hitung yang diperoleh }}$ lebih besar dari nilai tabel dan nilai signifikasi sebesar $0,047<0,05$, sehingga Ho ditolak. Dengan demikian dapat disimpulkan bahwa variabel kesadaran wajib pajak berpengaruh terhadap pendapatan asli daerah.

Berdasarkan analisis frekuensi tanggapan responden sebagaimana tabel 5.3 menunjukkan bahwa tanggapan pernyataan tentang apakah anda telah mendaftarkan diri sebagai wajib pajak dan memperoleh Nomor Pokok Wajib pajak (NPWP) ditanggapi dengan sangat setuju sebanyak $26,25 \%$ atau 22 responden, sebanyak $22,50 \%$ atau 18 responden menyatakan setuju, sebanyak 7,50\% atau 6 responden menyatakan kurang setuju dan sebanyak $31,25 \%$ atau 25 responden menyatakan tidak setuju serta sebanyak 7,50\% atau 6 responden menyatkan sangat tidak setuju. Sedangkan tanggapan atas pernyataan apakah anda melakukan pemungutan pajak restoran atas dasar transaksi yang dilakukan oleh pelanggan adalah kewajiban saya sebagai seorang wajib pajak yang baik ditanggapai oleh $16,25 \%$ atau 13 responden dengan jawaban sangat setuju, sebanyak $31,25 \%$ atau 25 responden menyatakan setuju, selanjutnya sebanyak $45,00 \%$ atau 36 responden menyatakan kurang setuju dan sebanyak $7,50 \%$ atau 6 responden menyatakan tidak setuju.

Pernyataan apakah anda menyimpan bill bukti transaksi penjualan dan bukti pemungutan pajak restoran dan membuat pembukuan adalah kewajiban saya sebagai seorang wajib pajak yang baik, ditanggapi dengan jawaban sangat setuju sebanyak $25,00 \%$ atau 20 responden, sebanyak 22,50\% atau 18 responden menyatakan setuju. Dilanjutkan dengan jawaban kurang setuju sebanyak $11,25 \%$ atau 9 responden dan sebanyak $46,25 \%$ atau 37 responden menyatakan tidak setuju serta sebanyak 7,50\% atau 6 responden menyatakan sangat tidak setuju. Kemudian pernyataan pelaporan pajak (SPTPD) secara teratur dan tepat waktu setiap bulan adalah kewajiban saya sebagai seorang wajib pajak yang baik mendapatkan tanggapan sangat setuju sebanyak $8,75 \%$ atau 7 responden, sebanyak $21,25 \%$ atau 17 responden menyatakan setuju, sebanyak $50,00 \%$ menyatakan kurang setuju, dan sebanyak $20,00 \%$ atau 16 responden menyatakan tidak setuju. Sedangkan pernyataan tentang apakah anda melakukan Penghitungan pajak terhutang dengan jujur dan benar adalah kewajiban anda sebagai seorang wajib pajak yang baik dan melakukan penyetoran pajak secara teratur dan tepat waktu ditanggapi dengan jawaban sangat setuju sebanyak $13,75 \%$ atau 11 responden, jawaban setuju oleh $23,75 \%$ atau 19 responden dan sebanyak 45,00\% atau 36 responden kurang setuju serta sebanyak $17,50 \%$ atau14 responden menyatakan tidak setuju.

Penelitian ini bertolak belakang dengan penelitian Fitria, Kurnia Nengsih (2017) yang menyatakan bahwa Kesadaran wajib pajak kendaraan secara parsial tidak mempengaruhi kepatuhan wajib pajak kendaraan hal ini terkait dengan meningkat tidaknya penerimaan asli daerah di Sumatera Barat. Dan juga bertolak belakang dengan penelitian Dewi Olivia dan 
Retnaningtyas Widuri (2013) yang menyatakan bahwa kesadaran wajib pajak tidak berpengaruh terhadap PAD Kota Tarakan.

\section{Sosialisasi berpengaruh terhadap pendapatan asli daerah Kota Banjarbaru}

Adanya sistem pembayaran pajak maupun ketentuan-ketentuan bagi wajib pajak maka perlu di lakukan sosialisasi yang terus menerus sebagai upaya dalam mengingatkan wajib pajak akan tanggungjawabnya dalam membayar pajak. Demikian halnya dalam mensosialisasikan sistem pajak kepada wajib pajak restoran, semakin itensif dalam melakukan sosialisasi maka semakin banyak wajib pajak restoran yang tersosialisasi, semakin banyak wajib pajak yang membayar pajak sehingga hal ini mempengaruhi peningkatan pendapatan asli daerah Kota Banjarbaru.

Hal ini sejalan dengan hasil penelitian bahwa pengaruh sosialisasi berdasarkan output hasil uji tabel 5.15 diketahui nilai thitung untuk variabel sosialisasi sebesar 23,284. Dengan membandingkan hasil nilai $t_{\text {hitung }}>t_{\text {tabel }}(23,284$ $>1,665)$ maka $t_{\text {hitung }}$ yang diperoleh lebih besar dari nilai t-abel dan nilai signifikasin diperoleh $0,000<0,05$, sehingga Ho dtolak. Dengan demikian dapat disimpulkan bahwa variabel sosialisasi berpengaruh signifikan terhadap pendapatan asli daerah.

Berdasarkan analisis frekuensi tanggapan responden sebagaimana tabel 5.4 di atas menunjukkan bahwa pernyataan tentang sosialisasi yang dilakukan oleh Badan Pengelolaan Pajak dan Retribusi menambah pengetahuan tentang peraturan pajak restoran mendapatkan tanggapan sangat setuju oleh $26,25 \%$ atau 21 responden, sebanyak $30,00 \%$ atau 24 responden menyatakan setuju, dan $36,25 \%$ atau 29 responden menyatakan kurang setuju, sementara tanggapan tidak setuju oleh sebanyak 7,505 atau 6 responden. Sedangkan pernyataan tentang teknologi informasi yang digunakan oleh Badan Pengelolaan Pajak dan Retribusi untuk pelayanan sudah cukup modern mendapatkan tanggapan sangat setuju sebanyak $32,50 \%$ atau 26 responden, sebanyak $22,50 \%$ atau 18 responden menyatakan setuju, sebanyak $11,25 \%$ atau 9 responden menyatakan kurang setuju, dan sebanyak $27,50 \%$ atau 22 responden menyatakan tidak setuju serta sebanyak $6,25 \%$ atau 5 responden menyatakan sangat tidak setuju.

Pernyataan tentang dalam setiap sosialisasi apakah anda diberikan cara dalam melakukan pengisian formulir dan cara melaporkan pajak restoran mendapatkan tanggapan sangat setuju sebanyak $20.00 \%$ atau 16 responden, jawaban setuju sebanyak $33,75 \%$ atau 27 responden, sebanyak $38,75 \%$ atau 31 responden menyatakan kurang setuju dan sebanyak $7,50 \%$ atau 6 responden menjawab tidak setuju. Sedangkan pernyataan tentang sosialisasi yang dilaksanakan telah tepat sasaran yaitu para calon wajib pajak, wajib pajak baru dan wajib pajak terdaftar mendapatkan tanggapan sangat setuju oleh $21,25 \%$ atau 17 responden, tanggapan setuju sebanyak $28,75 \%$ atau 23 responden, sebanyak $16,25 \%$ atau 13 responden menjawabkurang setuju, dan sebanyak $33,75 \%$ atau 27 responden menjawab tidak setuju. Dan pernyataan tentang program ekstensifikasi atau sosialisasi yang terus menerus dilakukan oleh Badan Pengelolaan Pajak dan Retribusi akan berdampak positif dalam meningkatkan kesadaran wajib pajak mendapatkan tanggapan sangat setuju sebanyak $22,50 \%$ atau 18 responden, sebanyak $31,25 \%$ atau 25 responden menyatakan setuju, dan sebanyak $37,50 \%$ atau 30 responden menyatakan kurangsetuju serta sebanyak $8,75 \%$ atau 7 responden menyatakan tidak setuju.

Penelitian ini sejalan dengan penelitian Murdliatin (2015) dan Hamta (2017) bahwa sosialisasi perpajakan berpengaruh signifikan secara parsial maupun simultan terhadap kepatuhan wajib pajak dalam meningkatkan pendapatan asli daerah Kota Malang. Meningkatnya kepatuhan wajib pajak dalam membayara pajak, maka semakin meningkatan pendapatan asli daerah dari sektor pajak.

\section{Variabel pelaporan, kesadaran wajib pajak dan sosialisasi yang berpengaruh dominan terhadap pendapatan asli daerah Kota Banjarbaru}

Berdasarkan hasil penelitian, dari ketiga variabel independen dalam penelitian yaitu variabel laporan, variabel kesadaran wajib pajak dan variabel sosialisasi dalam mempengaruhi variabel dependen yaitu variabel pendapatan asli daerah berdasarkan hasil uji t menunjukan hasil bahwa variabel independent yang paling dominan dalam mempengaruhi variabel 
pendapatan asli daerah adalah variabel sosialisasi dengahasil uji t sebesar 23,284, nilai hasil uji t ini jauh lebih besar dari nilai hasil uji t dua variabel independen yang lainnya yaitu variabel laporan dan variabel kesadaran wajib pajak.

Sosialisasi sistem dalam perpajakan bukan hanya sekedar aturan-aturan terkait dengan kewajiban pembayaran, namun juga terkait dengan sanksi-sanksi yang akan diberikan kepada wajib pajak yang melalaikan dalam pembayaran pajak. Sosialisasi sistem perpajakan memberikan pengetahuan kepada wajib pajak sehingga hal ini menimbulkan kesadaran diri akan kewajiban dalam membayar pajak, sehingga dapat menumbuhkan kepatuhan wajib akan kewajiban membayar pajak.

\section{PENUTUP \\ Kesimpulan}

Berdasarkan hasil penelitian dan analisis data serta pembahasan maka dapat diambil kesimpulan sebagai berikut:

1. Pelaporan, kesadaran wajib pajak dan sosialisasi sistem secara simultan berpengaruh signifikan terhadap pendapatan asli daerah Kota Banjarbaru

2. Secara parsial pelaporan, kesadaran wajib pajak dan sosialisasi berpengaruh signifikan terhadap pendapatan asli daerah Kota Banjarbaru

3. Variabel yang berpengaruh dominan terhadap pendapatan asli daerah Kota Banjarbaru adalah sosialisasi, karena nilai signifikan lebih besar pengaruhnya Saran dibanding dengan variabel yang lain.

Berdasarkan kesimpulan diatas, maka dalam penelitian ini penulis menyarankan:

1. Sosialisasi sistem perpajakan wajib digalakkan dan lebih ditingkatkan untuk menyadarkan wajib pajak utamanya wajib pajak restoran di Kota Banjarbaru.

2. Perlu tindakan tegas atau pemberian sanksi baik peringatan maupun pencabutan perijinan jika pihak wajib pajak terbukti melalaikan kewajibannya dalam membayar pajak.

\section{DAFTAR PUSTAKA}

Adriani. 2014. Teori Perpajakan. Jakarta: Salemba Empat.

Alfian, R. 2013. Pengaruh Kepatuhan Wajib Pajak Orang Pribadi Terhadap Penerimaan Pajak di KPP Pratama Surabaya Krembangan. Jurnal Akuntansi Vol. 1, No. 3. Surabaya: Universitas Negeri Surabaya.

Amanda, C. P. 2014. Pengaruh Kesadaran Wajib Pajak, Sanksi Pajak, Pelayanan Fiskus dan Pemeriksaan Pajak Terhadap Kepatuhan Wajib Pajak Orang Pribadi Di Kota Padang. Jurnal Ekonomi Vol. 4, No. 1. Padang: Universitas Bung Hatta.

Arikunto. 2013. Prosedur Penelitian: Suatu Pendekatan Praktik. Jakarta: Rineka Cipta.

Badan Pendapatan Pengelolaan Pajakdan Retribusi Daerah (BPPRD) Kota Banjarbaru, 2018. Daftar PenerimaanPajak Daerah Kota Banjarbaru, Tahun 2015-2018.

Badan Pengelolaan Pajakdan Retribusi Daerah (BPPRD) Kota Banjarbaru, 2018. Daftar Jumlah Wajib Pajak Restoran Kota Banjarbaru, Tahun 2018.

Badan Pengelolaan Pajak dan Retribusi Daerah (BPPRD) Kota Banjarbaru, 2018. Daftar Target dan Realisasi Penerimaan Pajak Restoran Kota Banjarbaru, Tahun 2015 2018.

Badan Pengelolaan Pajakdan Retribusi Daerah (BPPRD) Kota Banjarbaru, 2018. Daftar Penerimaan Pajak Restoran Kota BanjarbaruTahun 2015-2018.

Busrizalti, H.M. 2013. Hukum Pemda: Otonomi Daerah dan Implikasinya. Yogyakarta: Total Media.

Fitria, Kurnia Nengsih, 2017. Pengaruh Kesadaran Wajib Pajak Dan sanksi administrasi terhadap kepatuhan wajib pajak kendaraan bermotor dan Kaitannya terhadap PAD di Sumatera Barat. Universitas Andalas.

Ghozali, I. 2016. Aplikasi Analisis Multivariate Dengan Program IBM SPSS 20. Semarang: BPFE Universitas Diponegoro.

Hamta, Firdaus, 2017. Pengaruh Kualitas Pelayanan Dan Sosialisasi Pajak Terhadap Kepatuhan Pajak dalam meningkatkan PAD Kota Batam. Jurnal equilibira, Volume 4 No. 1 Tahun 2017 
KBBI. 2017. Kamus Besar Bahasa Indonesia (KBBI). Diakses dari http://kbbi.web.id/. (Diakses 9 September2017).

Kemala, W. 2015. Pengaruh Kesadaran Wajib Pajak, Pengetahuan Pajak, Sikap Wajib Pajak dan Reformasi A '. 'strasi Perpajakan Terhadap Kepat. 10 Wajib Pajak Kendaraan Bermotor. Jurnal Ekonomi Vol, 2. No, 2. Pekanbaru: Fakultas Ekonomi Universitas Riau.

Mardiasmo. 2012. Perpajakan Edisi Revisi Hal 1 dan 12. Yogyakarta: Andi.

-------- 2013. Perpajakan Edisi Revisi. Yogyakarta: Andi.

Murdliatin, Nur. 2015. Pengaruh Kualitas Pelayanan, Sosialisasi Perpajakan Dan Pengetahuan Perpajakan Terhadap Kepatuhan Wajib Pajak dalam meningkatkan PAD Kota Malang. Jurnal Mahasiswa Perpajakan, Volume 5, No 2 tahun 2015.

Mulyadi, M. 2016. Metode Penelitian Praktis Kualitatif \& Kuantitatif. Jakarta: Publica Press.

Notohatmodjo, B. S. 2017. Pengaruh Pemahaman, Kesadaran Pajak, Pelayanan Fiskus dan Sanksi Pajak Terhadap Kepatuhan Wajib Pajak Orang Pribadi (Studi di Wilayah Kerja KPP PratamaTigaraksa). Jurnal Ilmiah Akuntansi Vol,1. No,1. Purworejo: Politeknik Sawunggalih Aji.

Nugroho J. Setiadi. 2013. Perilaku Konsumen (edisi revisi). Jakarta : Kencana Perdana Media Grup

Olivia, Dewi Dan Retnaningtyas Widuri, 2013. Faktor-Faktor Yang Mempengaruhi Keberhasilan Penerimaan Pendapatan Asli Daerah Kota Tarakan. Tax \& Accounting Review, Volume 3, NO.2, 2013, Akuntansi Universitas Kristen Petra

Republik Indonesia. 2009. Undang-Undang Nomor 28 Tahun 2009. Tentang Pajak Daerah dan Retribusi Daerah.

Republik Indonesia. 1997. Undang-Undang Nomor 18 Tahun 1997. Tentang Pajak Daerah dan Retribusi Daerah.

-- 2004. Undang-Undang Nomor 32 Tahun 2004. Tentang Pemerintahan Daerah.

--- 2000. Undang-Undang Nomor 34 Tahun 2000. Tentang Perubahan Atas
Undang-Undang Republik Indonesia Nomor 18 Tahun 1997. Tentang Pajak Daerah dan Retribusi Daerah.

2009. Undang-Undang Nomor 16

Tahun 2009. Tentang Ketentuan Umum dan Tata Cara Perpajakan.

2004. Undang-Undang Nomor 33

Tahun 2004. Tentang Perimbangan Keuangan Antara Pemerintah Pusat dan Pemerintah Daerah.

-- 2009. Undang-Undang Nomor 29

Tahun 2009. Tentang Pajak Daerah dan Retribusi Daerah, Pajak Daerah.

--- 2004. Undang-Undang Nomor 32

Tahun 2004. Tentang Pemerintahan Daerah.

2003. Peraturan Mentri
KeuanganTahun 2003, Tentang Jasa
Boga dan Katering, PMK
(418/KMK.03/2003).
--- 2001. Peraturan Pemerintah Republik
Indonesia Nomor 65 Tahun 2001, Tentang
Pajak Daerah.

Resmi, S. 2013. Perpajakan; Teori dan Kasus.

Edisi 7. Jakarta: Salemba Empat.

Riyanto, T. H. 2012. Faktor-Faktor Yang Mempengaruhi Kepatuhan Wajib Pajak Di KPP Jakarta Tahun 2009-2011. Tesis. Jakarta: Fakultas Ekonomi Univeritas Indonesia.

Sari, D. 2013. Konsep Dasar Perpajakan. Bandung: PT Refika Adimata.

Siahaan, P. M. 2016. Pajak Daerah dan Retribusi Daerah. Edisi Revisi. Jakarta: Rajawali Press.

Sugiyono. 2013. Metode Penelitian Kunatitatif Kualitatif dan R\&D. Bandung: Alfabeta.

2014. Metode Penelitian Kunatitatif Kualitatif dan R\&D. Bandung: Alfabeta. 2016. Metode Penelitian: Kuantitatif, Kualitatif, dan $R \& D$. Bandung: Alfabeta.

Sujarweni. 2014. Metode Penelitian: Lengkap, Praktis, dan Mudah Difahami. Yogyakarta: Pustaka Baru Press.

Sukrisno, A. 2014. Akuntansi Perpajakan Edisi 3. Jakarta: Salemba Empat.

Sumarsan, T. 2013. Perpajakan Indonesia Volume 3. Jakarta: PT. Indeks.

Tjiptono, F. 2014. Pemasaran Jasa. Yogyakarta: Andi.

Tulenan, A. Sondakh, J. Pinatik, S. 2017. Pengaruh Kesadaran Wajib Pajak, 
Kualitas Pelayanan dan Sanksi Pajak Terhadap Kepatuhan Wajib Pajak Orang Pribadi Di KPP Pratama Bitung. Jurnal Riset Akuntansi 296-303. Manado: FEB Universitas Sam Ratulangi.

Utami, T, D, Kardinal. 2013. Pengaruh Kesadaran Wajib Pajak dan Sanksi Pajak Terhadap Kepatuhan Wajib Pajak Orang Pribadi Pada KPP Pratama Palembang. Jurnal Riset Akuntansi Going Concern 12(2), 296-303. Seberang Ulu: STIE MDP.

Waluyo. 2013. Perpajakan Indonesia. Jakarta: Salemba Empat. 